\title{
Lessons learned from blunt trauma abdomen: Surgical experience in level I trauma centre
}

\author{
Amit Singh ${ }^{1}$ (D), Ganpat Prasad² (D), Prabhakar Mishra ${ }^{3}$ (D), Kuldeep Vishkarma ${ }^{1}$ (D), Rafat Shamim² (D) \\ 1 Division of Trauma, Sanjay Gandhi Post Graduate Institute of Medical Sciences, Lucknow, India \\ ${ }^{2}$ Division of Anaesthesia, Sanjay Gandhi Post Graduate Institute of Medical Sciences, Lucknow, India \\ ${ }^{3}$ Division of Biostat, Sanjay Gandhi Post Graduate Institute of Medical Science, Lucknow, India
}

\begin{abstract}
Objective: The number of accident cases is increasing day by day, so as the challenges. With an emphasis on trauma care, the government started a 120 bedded level I trauma centre in northern India catering to a population of 2.8 million in June 2018 . Through this article, we aimed to share our experience of blunt abdominal trauma management from a new level I trauma centre.

Material and Methods: In this retrospective observational study, historical analysis of all available records from July 2018 to March 2020 was done. Inclusion criteria included blunt trauma abdomen with or without associated injuries. Data regarding age, sex, mechanism of injury, time taken to reach the hospital, the pattern of solid organs and hollow viscus injuries, associated extra abdominal injuries, mode of treatment, complications, length of ICU and hospital stay, and mortality were reviewed.

Results: Overall, 154 cases sustained abdominal injuries during the study period. Seventy-five percent were male. The most common cause of blunt trauma abdomen was road traffic crashes. Operative management was required in 57 (37.01\%) cases while 97(62.98\%) were managed non-operatively (NOM). Mean ICU stay was 05.73 days, while the average hospital stay was 12 days (range 10-60 days). Procedures performed included splenectomy, liver repair, primary closure of bowel injury, and stoma formation. Complications occured in $16.88 \%$ cases and the overall mortality rate was $11.68 \%$.

Conclusion: The study revealed that among 154 cases of fatal blunt abdominal trauma, road traffic crash was the most common cause of blunt abdominal trauma, predominantly affecting males. The visceral and peritoneal injury frequently perceived was liver in 40 cases (25.9\%), spleen 66 (43\%), intestine $21(13.6 \%)$ and kidney 13 cases (09\%). Abdominal injury was associated with other injuries like head, chest and extremity injuries in 52.5\% cases. Duration of injury, presence of associated injury and preoperative ventilation requirement were independent predictors of mortality apart from contributary factors such as clinical presentation, organ involved and presence of complications.
\end{abstract}

Keywords: Motor vehicle accidents, trauma, abdominal injuries, outcome, prehospital care

Cite this article as: Singh A, Prasad G, Mishra P, Vishkarma K, Shamim R. Lessons learned from blunt trauma abdomen Surgical experience in level I trauma centre. Turk J Surg 2021; 37 (3): 277-285

\section{Corresponding Author}

Amit Singh

E-mail: amitsgpgi81@gmail.com

Received: 07.08 .2020

Accepted: 16.07 .202

Available Online Date: 28.09.202

() Copyright 2021 by Turkish Surgical Society Available online at www.turkjsurg.com

DOI: $10.47717 /$ turkjsurg.2021.4886

\section{INTRODUCTION}

In developing countries where modernization and industrialization are still going on, trauma emerges as a major cause of preventable death. In fact, at the present, trauma is the sixth leading cause of morbidity and mortality worldwide (1).The abdomen is the most frequently injured region after head injury and long bone fractures, and $25 \%$ of all abdominal trauma requires abdominal exploration $(2,3)$. In cases of pre-existing underlying pathology, even trivial trauma to the abdomen can lead to significant haemorrhage and mortality if remains undiagnosed. Traditionally, abdominal trauma is classified either as blunt or penetrating (4). Penetrating injuries include stab wounds and gunshot wounds while blunt abdominal injuries include motor vehicle crashes, fall from height, and physical assault (5). Blunt trauma abdomen is usually missed during the initial primary survey unless repeatedly looked for. In due course of time, this delay in diagnosis and inadequate management can prove fatal. It is imperative that we must supplement clinical examination with radiological imaging such as focused assessment with sonography in trauma (FAST) to diagnose free fluid in the peritoneal or pericardial cavity and contrast-enhanced computed tomography (CECT) torso to detect visceral abdominal and chest injuries. Blunt trauma to the abdomen can cause injuries to both solid and enteric viscera. Solid visceral injuries involve injuries to the spleen, liver, kidney, and present with signs of shock, whereas enteric injuries present with peritonitis and sepsis (6-9). 
Data regarding the etiology and outcome of abdominal injuries from our region is lacking. Hence, the primary objective of our study was to assess the etiology, causes, pattern of injury, and clinical outcome of blunt abdominal trauma cases while the secondary objective was to assess the predictors of mortality.

\section{MATERIAL and METHODS}

Retrospective analysis of data from the emergency room services of a 120-bed level I trauma centre was used to discuss the impact and outcome of only blunt abdominal injury cases. Historical analysis of case records of all patients admitted in the emergency from July 2018 to March 2020 was done after obtaining ethical clearance from the institutional ethical committee vide letter PGI/BE/447/2020 dated 10 July 2020. Informed written consent was taken routinely while admitting the cases. We included all cases of blunt trauma abdomen with or without associated injuries in the study. The present analysis excluded the cases of penetrating abdominal injuries, and those who died during the resuscitation without undergoing any imaging. Since the post-mortem facility in our institute was not available, records of post-mortem reports were neither traced nor analysed. All cases were initially managed according to the advanced trauma life support (ATLS) guidelines. All cases underwent FAST during the primary survey, and we subjected those who were FAST positive or suspected to have abdominal injuries to CT Torso. Our management protocol of blunt trauma abdomen was based primarily on hemodynamic stability. Unstable cases with FAST positive were directly shifted to the operation theatre, whereas we managed stable cases according to the CT Findings. Repeat radiological investigations (FAST/CECT) were done whenever required. We did initial management of all postoperative cases in the surgical intensive care unit. The patient was shifted to the surgical ward once he/she was off mechanical ventilation and was hemodynamically stable. By day $2 / 3$, we tried to start enteral feeding in all patients. Cases were discharged with proper discharge summary and advice. First follow up was in the surgical outpatient department (SOPD) after the first week. A proper record of all follow-up visits was maintained. We sent cases requiring rehabilitation to physical medicine and rehabilitation department for physiotherapy.

Data regarding age, sex, time taken to reach the hospital, the pattern of solid organs and hollow viscus injuries, associated extra-abdominal injuries, mode of treatment, complications, length of ICU and hospital stay, and mortality were reviewed. Length of ICU stay was defined as the period from admission to the ICU until transfer out from ICU. Hospital stay was defined as the period from admission until discharge or until in hospital death. Ventilator hours were defined as the number of hours the case was on mechanical ventilation. Mortality was defined as death during hospital stay either because of trauma or due to complications arising out of trauma. Continuous variable was presented as mean \pm standard deviation/median (Q1, Q3 i.e interquartile range) whereas categorical variables as frequency (\%). Independent samples t test and Mann Whitney $U$ test were used to compare the means/medians respectively between patient's outcomes (non-survivor and survivor). Time taken to reach the hospital was compared among three groups, using Kruskal Wallis H test. Chi-square test or Fisher's exact test was used to compare the proportions between the groups. In order to assess the predictors of the non-survivors, binary logistic regression analysis was used. Variables significantly associated with patients' outcomes were further used to estimate odds ratio in univariate analysis and adjusted odds ratio for multivariate analysis. P value $<0.05$ was considered as statistically significant. Statistical package for social sciences version-23 (SPSS-23, IBM, Chicago, USA) was used for data analysis.

\section{RESULTS}

Abdominal trauma was present in 179 of 1456 cases (12.29\%) presenting in the emergency department. Out of these 179 cases, 16 (8.9\%) were penetrating abdominal injury, hence excluded from the study. A total of 9 cases (5.02\%) died during resuscitation without undergoing any imaging, so we also excluded them. Out of 154 cases included in the study, an overwhelming majority was male $(117,75.97 \%)$ while 37 (24.02\%) were females, with a male to female ratio of 3.1:1 (Table 1). It is clear from Table 1 that the majority of cases in the present study were in 31-50 years age group $(106,68.8 \%)$, followed by $>51$ years age group $(24,15.5 \%)$. In the majority of cases $(103,67 \%)$, the immediate cause of abdominal trauma was road traffic crashes, followed by assault in $28(18.18 \%)$ and fall from height in 23 (14.93\%) cases. Sixty-seven (65\%) cases were four-wheeler occupants, while 36 (34.9\%) were two-wheeler occupants. 7 occupants of four-wheeler and 10 occupants of two-wheeler cases died as a result of injuries (Table 2). A total of 116 (75.3\%) cases used government ambulance to reach the hospital while 38 (24.6\%) cases used personal vehicles to reach the hospital. Out of these 116 cases, 14 did not survive while 4 cases died among those who used personal vehicles. However, there was no significant correlation ( $p$ value 0.745 ) found between the two modes of transport and mortality (Table 2). Overall, associated injuries were seen in 81(52.59\%) cases, with chest injuries being most common $(39,25.32 \%)$ followed by extremities injuries in 25 (16.23\%) and head injury in $17(11.03 \%)$ cases (Table 1). The majority of cases presented with abdominal distension $(57,37.01 \%)$, which was followed by pain in the abdomen in 49 (31.8\%), pain with guarding and rigidity in 29 (18.8\%), and shock in 19 (12.33\%) cases (Table 2). Sixty-one (39.61\%) cases reached our institute within 1-10 hours (Table 3). Twenty-four (15.5\%) cases reached after a delay of 11-20 hours. On comparing the time to reach in hospital with mode of injury, significant difference $(p<0.05)$ was seen between the various modes of injury although there was no significant difference ( $p>$ 
Table 1. Demographic profile, age, associated injury, and clinical presentation at time of admission

\begin{tabular}{|l|c|}
\hline Variables & No of cases $(\mathbf{n = 1 5 4 , \% )}$ \\
\hline $\begin{array}{l}\text { Age in years } \\
18-30\end{array}$ & $10(6.4 \%)$ \\
$31-40$ & $14(9.0 \%)$ \\
$41-50$ & $61(39.6 \%)$ \\
$>51$ & $45(29.2 \%)$ \\
\hline Sex & $24(15.5 \%)$ \\
\hline \multicolumn{1}{|c|}{ Male } & $117(75.9 \%)$ \\
\hline Associated injury & $37(24 \%)$ \\
\hline Chest & $81(52.5 \%)$ \\
\hline Head & $3925.3 \%)$ \\
Extremity & $25(16.2 \%)$ \\
\hline Clinical presentation at time of admission & $17(11.0 \%)$ \\
\hline Abdominal Distension & $57(37.0 \%)$ \\
\hline Pain only & $49(31.8 \%)$ \\
\hline Pain with Guarding/Rigidity & $29(18.8 \%)$ \\
\hline Shock & $19(12.3 \%)$ \\
\hline Presented in Frequency (\%) & \\
\hline
\end{tabular}

0.05) observed in the median duration of time to reaching hospital among three types of accidents (Table 3). The majority of cases $(97,62.98 \%)$ were managed non-operatively, while 57 (37.02\%) underwent emergency laparotomy. That means the ratio of NOM to operative method was 1:1.7. Details regarding organ of injury, mode of treatment and various surgical procedures performed are shown in Table 4. Out of these 57 cases, 48 (84.12\%) were taken for laparotomy either because of hemodynamic instability or due to feature of peritonitis. Failure of NOM occurred in 9 (9.2\%) cases. Out of these 9 cases, 5 cases were of pancreatic injury, who were given a trial of nonoperative management, but these cases ultimately underwent laparotomy because of severe abdominal distension in 3 and hemodynamic instability in the remaining 2 cases. Four cases of mesenteric injuries were also given a trial of $\mathrm{NOM}$, but because of the development of signs of peritonitis, we considered laparotomy after 48 hours of observation. Intraoperatively, the bowel was found to be in the pre gangrenous stage, requiring resection and anastomosis in all 4 cases (Figure 1a). Out of those 48 cases undergoing exploratory laparotomy, 8 (16.6\%) were shifted to OT without any radiological imaging except FAST because of hemodynamic instability. Damage control surgery was done in 7 (12.2\%) cases. Four of them were of liver injuries, in which only liver packing was done during the initial procedure and repeat exploration after 48 hours (Figure 1b). Two cases of splenic injuries required re-exploration within 24 hours of splenectomy because of increased drain output. On re-exploration, no bleeder was found and packing of splenic fossa was done. We removed the pack after 48 hours. In 1 case of urinary bladder injury who presented with associated pelvic injury and gross hemoperitoneum, damage control surgery with the packing of retro vesical space, application of external fixator, and intraperitoneal repair of urinary bladder was done. In 3 of our cases, who underwent laparotomy, no obvious solid or visceral injuries were found apart from hemoperitoneum caused either by mesenteric injury or retroperitoneum hematoma. We did emergency intubation in the receiving area in 27 (17.5\%) cases. During the postoperative period, we shifted all cases in the surgical ICU as per our departmental protocol. The patient was shifted to the surgical ward once he/ she was off mechanical ventilation and was hemodynamically stable. Mean ICU stay was 5.73 days, (range 3-18 days) while the average hospital stay was 12 days ranging from 4 to 60 days. Overall complication rate was $16.88 \%$ (26) cases. Postoperative complications observed in our study included septicemia in 9 (5.8\%), anastomotic leak in $3(1.9 \%)$, and pancreatic fistula in 2 (1.29\%) cases. Twelve (7.7\%) of our cases required dialysis for acute renal failure, out of whom 3 (1.94\%) died during the treatment. Overall mortality rate was $11.68 \%$ (18 cases). Out of these 18 cases, 7(4.54\%) died while on conservative management because of associated grievous head injuries while 11 (7.14\%) died in the postoperative period. Further analysis of data showed that the mean age of non survivors in the present study was $32.21 \pm 11.38$ years, while for survivors it was $29.16 \pm 14.80$ years. The male: female ratio in the non-survivor group was 5:1. That means for every 5 men, 1 female died due to injury. There was no significant statistical difference between the two age groups or sex (p 0.389, 0.160 , 0.002 respectively). However, significant statistical difference was found for duration of injury, ICU stay, and ventilation hours ( $p$ value $0.023,0.002,<0.001$ ) (Table 2). In order to assess the predictors of the non-survivor, binary logistic regression analysis was used. Out of various analysed variables, only 7 variables came out to be significantly associated with patients' outcomes which were further used to estimate odds ratio in univariate analysis and adjusted odds ratio for multivariate analysis (Table 5). In univariate analysis, duration of injury, clinical symptoms, any complications, pre-op ventilation, and organs involved in the injury were found to be possible factors for mortality. In multivariate analysis, out of the above variables, only two variables i.e. duration of injury (adjusted Odds ratio: 1.03 (95\% Cl: 1.01-1.04, p< 0.05) and associated injury (adjusted Odds ratio: 4.85, 95\% Cl: 1.42-16.52, $p<0.05$ ) showed significant and independent risk factor for patient mortality (Table 5).

\section{DISCUSSION}

Blunt trauma abdomen can be called a silent killer because if not managed properly, the results can be catastrophic. Despite the recent advances in imaging techniques, the evaluation and diagnosis of intra-abdominal injuries still remain a challenge for 
Table 2. Distribution of demographic and clinical variables between the Non-Survivor and Survivor Groups

\begin{tabular}{|c|c|c|c|}
\hline Variables & Non-Survivor $(n=18)$ & Survivor $n=136$ ) & $\mathbf{P}$ \\
\hline Age & $32.21 \pm 11.38$ & $29.16 \pm 14.80$ & $0.389 \$$ \\
\hline Sex (Female) & $3(15.7 \%)$ & $34(25.1 \%)$ & 0.160 \\
\hline Sex (Male) & $15(83.3 \%)$ & $102(75 \%)$ & 0.002 \\
\hline Duration of Injury & $48(7,96)$ & $12(6,48)$ & $0.023^{\#}$ \\
\hline Hospital stay & $6(4,18)$ & $10(9,13)$ & $0.926^{\#}$ \\
\hline ICU stay & $7(5,18)$ & $4(3,5)$ & $0.002^{\#}$ \\
\hline Ventilator hours & $96(72,96)$ & $48(24,72)$ & $<0.001^{\#}$ \\
\hline Four-wheeler & $7(38.8 \%)$ & $60(44.1 \%)$ & 0.457 \\
\hline Two-wheeler & $10(55.5 \%)$ & $26(19.1 \%)$ & 0.541 \\
\hline Mode of Injury & & & 0.881 \\
\hline RTA & $12(66.6 \%)$ & $91(67.4 \%)$ & 0.986 \\
\hline Fall from Height & $4(22.2 \%)$ & $19(14 \%)$ & 0.604 \\
\hline Assault & $2(16.6 \%)$ & $26(18.3 \%)$ & 0.614 \\
\hline Mode of transport to hospital & & & 0.999 \\
\hline Ambulance & $14(77.7 \%)$ & $102(75.6 \%)$ & 0.745 \\
\hline Personal vehicle & $4(21.1 \%)$ & $34(25 \%)$ & 0.746 \\
\hline Clinical symptoms & & & $<0.001$ \\
\hline Tenderness & $5(5.3 \%)$ & $24(17.6 \%)$ & 0.005 \\
\hline Pain & $1(5.5 \%)$ & $48(35.2 \%)$ & 0.141 \\
\hline Shock & $3(10.5 \%)$ & $16(11.7 \%)$ & $<0.001$ \\
\hline Distension & $9(50 \%)$ & $48(35.2 \%)$ & 0.038 \\
\hline Treatment mode & & & 0.094 \\
\hline Non-operative & $7(38.8 \%)$ & $91(66.9 \%)$ & 0.094 \\
\hline Operative & $11(61.1 \%)$ & $46(33.8 \%)$ & 0.058 \\
\hline Complications & $7(36.8 \%)$ & $8(5.9 \%)$ & $<0.001$ \\
\hline Preop ventilation & $16(84.2)$ & $11(8.1 \%)$ & $<0.001$ \\
\hline Type of injury & & & 0.042 \\
\hline No injury & $4(21.1 \%)$ & $72(52.6 \%)$ & 0.01 \\
\hline Head Injury & 10 (52.6\%) & $7(5.1 \%)$ & 0.001 \\
\hline Other Injury & $4(2.2 \%)$ & $60(44.1 \%)$ & 0.116 \\
\hline \multicolumn{4}{|c|}{$\begin{array}{l}\text { RTA: Road traffic accident. } \\
\$ \text { Mean } \pm \text { Standard deviation compared by Independent samples } t \text { test } \\
\text { \# Median (Q1, Q3 i.e. Interquartile range) compared by Mann Whitney } \mathrm{U} \text { test. } \\
\text { Frequency (\%) compared by Chi square test used or Fisher exact test. } p<0.05 \text { significant. }\end{array}$} \\
\hline
\end{tabular}

the treating doctors (10). In addition, delay or missed diagnosis leads to increased morbidity and mortality (11). The reported incidence of intra-abdominal injury is approximately $13 \%$ with bowel and mesenteric injuries occurring in 1-5\% of cases $(12,13)$. In this study, mean age of the males was $29+/-13$ years, and the female mean age was $28+/-16$ years. The majority of our cases were of the young productive age group, a finding which aligns with previous studies (14). Our study showed male predominance of the victims (75.9\%). Fleming $S$ et al. have found that in a group of 100 cases, $62 \%$ were men (15). In a study by Farahmand $\mathrm{N}$ et al., 60\% were male cases, which was comparable to our observations (16). In our study, the incidence of the mode of injuries was similar as reported in the literature (17-19). Among the road traffic crashes, the majority of cases were four-wheeler occupants $(67,65 \%)$ followed by two-wheeler occupants (36, 34.9\%). Forty-four percent of the four-wheeler occupants survived as compared to $19 \%$ of two-wheeler occupants. The average duration to reach our institution was 14.56 
Table 3. Association between time to reach to hospital and the organ involved with mode of injury

\begin{tabular}{|c|c|c|c|c|c|}
\hline \multirow[b]{2}{*}{$\begin{array}{l}\text { Time to reach to } \\
\text { hospital in hours }\end{array}$} & \multicolumn{5}{|c|}{ Patients with mode of Injury (154) } \\
\hline & $\begin{array}{c}\text { RTI A }(n=103 \\
66.8 \%)\end{array}$ & $\begin{array}{l}\text { Fall from height B } \\
\qquad(n=23,14.9 \%)\end{array}$ & $\begin{array}{c}\text { Assault C }(n=28, \\
18.3 \%)\end{array}$ & $\mathrm{p}$ & $\begin{array}{l}\text { Multiple comparisons } \\
\text { between pairs }(p<0.05)\end{array}$ \\
\hline $0-10$ & $37(36.0)$ & $13(56.5)$ & $11(39.28)$ & $<0.001$ & $A B, A C$ \\
\hline $11-20$ & $18(17.5)$ & $4(17.3)$ & $2(7.1)$ & $<0.001$ & $A B, A C$ \\
\hline $21-30$ & $12(11.6)$ & - & $2(7.1)$ & 0.014 & $A C$ \\
\hline $31-40$ & $3(2.9)$ & $1(4.3)$ & $2(7.1)$ & 0.027 & $A B$ \\
\hline $41-50$ & $9(8.7)$ & $1(4.3)$ & $2(7.1)$ & $<0.001$ & $A B, A C, B C$ \\
\hline $51-60$ & $3(2.9)$ & $2(8.6)$ & $1(3.5)$ & & - \\
\hline $61-70$ & $4(3.9)$ & - & $2(7.1)$ & & - \\
\hline $71-80$ & $8(7.8)$ & - & $2(7.1)$ & 0.039 & $A C$ \\
\hline $81-90$ & $3(2.9)$ & $1(4.3)$ & - & 0.826 & - \\
\hline $91-100$ & $4(3.9)$ & - & $3(10.7)$ & 0.568 & - \\
\hline $101-110$ & 2(1.9) & $1(4.3)$ & $1(3.5)$ & 0.999 & - \\
\hline Median (Q1, Q3) & $12(6,48)$ & $12(7,48)$ & $12(4,72)$ & 0.962\# & - \\
\hline \multicolumn{6}{|l|}{ Organ Involved } \\
\hline Liver & $27(26.2)$ & $4(17.5)$ & $9(32.2)$ & $<0.001$ & $A B, A C, B C$ \\
\hline Spleen & $39(37.8)$ & $17(73.9)$ & $10(35.6)$ & $<0.001$ & $A B, A C, B C$ \\
\hline Gall Bladder & $4(3.9)$ & - & - & - & - \\
\hline Pancreas & $4(3.9)$ & - & $1(3.5)$ & 0.034 & $A C$ \\
\hline Small & $11(10.7)$ & - & $2(7.1)$ & 0.47 & $A C$ \\
\hline Large bowel & $5(4.8)$ & $1(4.3)$ & $2(7.1)$ & 0.024 & $A B, A C$ \\
\hline kidney & $8(7.8)$ & $1(4.3)$ & $4(14.5)$ & $<0.001$ & $A B, A C, B C$ \\
\hline Urinary Bladder & $3(2.9)$ & - & - & - & \\
\hline Urethra & $2(1.9)$ & - & - & - & \\
\hline
\end{tabular}

hours. Thirty-nine percent of the cases reached in our institution within 1-10 hours of sustaining the injury, followed by $15.5 \%$ in the next 11-20 hours. We tried to correlate the time taken to reach the hospital with the mode of injury and found that cases involved in motor vehicle crashes reached hospital early as compared to cases of fall from height or assault. An explanation for this significant difference could be the obvious visible injuries during the crashes. Co-passenger or the people around the site of crashes also help in early referral to nearby healthcare centres either by dialling 108 or 100 . Whereas, individual injuries occurring during an assault or fall from height remain unnoticed until grievous in nature. We found the spleen to be the most commonly injured organ as against the liver which was reported in other series (20-22). Injury to the intestine was seen in $13.6 \%$, majority of which due to road traffic crashes. Jagannatha et al. have found this incidence to be $25 \%$, which is in concurrence with our study (23). The incidence of renal injury was 9\% in agreement with Khichi et al. (16.3\%), Meng MV et al. (10\%) and Sah D et al. (11.4\%) (24-26). Gall bladder injury was seen in $2.5 \%$ cases, comparable to the findings of Singh et al. (7.07\%) (27). We also tried to correlate the organ involved with the mode of injury and concluded that the spleen, liver, and small bowel were the commonly injured organs both in road traffic crashes and assault (Table 3). As can be seen from Table 3, road traffic crashes are responsible not only for the majority of solid organ injury but also for hollow viscus injury as well. In our series, all 3 cases of bladder injuries and 2 cases of urethral injury were because of motor vehicle crashes. All of these 5 cases were associated with pelvic fractures. For pelvic fractures, we did pelvic stabilization with an external fixator in the same setting. We found intraperitoneal rupture of the bladder in 3 cases, which was repaired primarily during laparotomy. Railroad technique along with suprapubic cystostomy was used in two cases who presented with urethral injury. One of these 2 cases required an 
Table 4. Organ of injury and various surgical procedures performed

\begin{tabular}{|c|c|c|c|c|c|}
\hline SI no & Injured organ & $\begin{array}{l}\text { Total no of case (\%) } \\
\qquad(n=154)\end{array}$ & $\begin{array}{c}\text { No of non-operated } \\
\text { cases (\%) }\end{array}$ & $\begin{array}{c}\text { No of operated } \\
\text { cases (\%) }\end{array}$ & Surgical procedure performed \\
\hline 1. & Liver & $40(25.9 \%)$ & $27(67.5 \%)$ & $13(32.5 \%)$ & Hepatic resection/repair \\
\hline 2. & Gall bladder & $04(2.5 \%)$ & - & $04(2.5 \%)$ & Cholecystectomy \\
\hline 3. & Spleen & $66(43 \%) *$ & $57(86.3 \%)$ & $09(13.6 \%)$ & Splenectomy \\
\hline 4. & Pancreas & $05(3.2 \%)$ & - & 05 (100\%) & Spleenopancreatectomy \\
\hline 5. & Kidney & $13(09 \%)$ & $10(76.9 \%)$ & $03(23.0 \%)$ & Nephrectomy \\
\hline 6. & $\begin{array}{l}\text { Intestines (Small/ } \\
\text { large/mesentery) }\end{array}$ & $21(13.6 \%)^{*}$ & $06(28.5 \%)$ & $15(71.4 \%)$ & $\begin{array}{c}\text { Primary bowel repair /Mesenteric } \\
\text { tear repair/Resection anastomosis/ } \\
\text { stoma formation }\end{array}$ \\
\hline 7. & Urinary Bladder & $03(1.9 \%)$ & - & $03(100 \%)$ & Intraperitoneal Bladder repair \\
\hline 8. & Urethra & $02(1.2 \%)$ & - & $02(100 \%)$ & Urethral repair \\
\hline
\end{tabular}
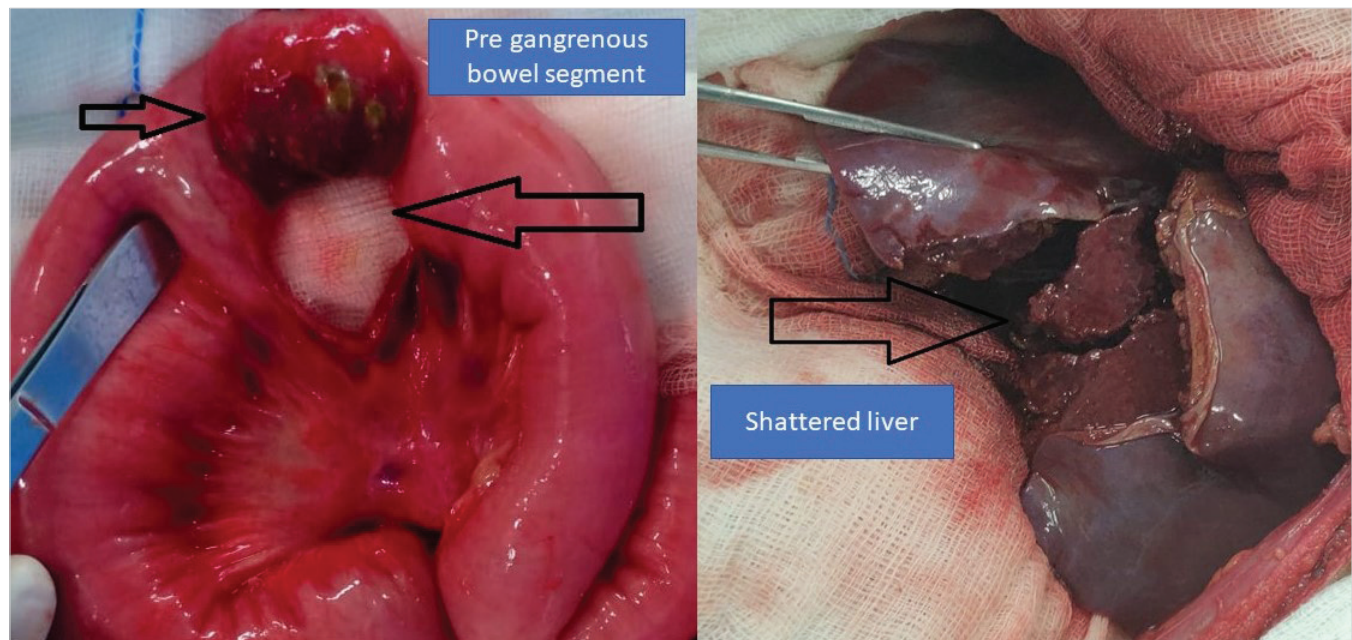

Figure 1. A. Pregangrenous segment of bowel, B. Hepatic Injury where packing was done as damage control surgery.

Table 5. Predictors of mortality $(n=154)$

\begin{tabular}{|c|c|c|c|c|}
\hline & Univariate analysis \# & & Multivariate analysis \$ & \\
\hline Variables & OR $(95 \mathrm{Cl})$ & $\mathrm{p}$ & AOR $(95 \mathrm{Cl})$ & $\mathrm{p}$ \\
\hline Duration of Injury & $1.02(1.01-1.04)$ & $<0.001$ & $1.03(1.01-1.04)$ & $<0.001$ \\
\hline Clinical Symptoms (Yes) & & $<0.001$ & -- & -- \\
\hline Tenderness (Yes) & $0.46(0.04-5.25)$ & 0.532 & -- & -- \\
\hline Pain (Yes) & $1.31(0.18-9.80)$ & 0.790 & -- & - \\
\hline Shock (Yes) & $80.5(13.3-486.8)$ & $<0.001$ & -- & -- \\
\hline Distension (Yes) & Ref & & -- & -- \\
\hline Any Complications (Yes) & $9.26(2.86-29.97)$ & $<0.001$ & -- & -- \\
\hline Pre-op Ventilation (Yes) & $60.1(15.2-238.7)$ & $<0.001$ & -- & - \\
\hline Any Associated Injuries (Organs involved in Injury) & $4.16(1.31-13.19)$ & 0.015 & $4.85(1.42-16.52)$ & 0.012 \\
\hline
\end{tabular}


end to end urethral anastomosis, which was done by the urology department of our institute. Analysis of our data showed that the most common presenting symptom was abdominal distension as against abdominal pain reported in other series (28). Delayed presentation leading to gross hemoperitoneum or perforation peritonitis was the reason, as can be seen that $12.33 \%$ of our cases presented with shock. In our study, we observed associated injuries in 81 (52.59\%) cases while there was no association in 73 (47.40\%) cases. Nikhil Mehta et al., in their retrospective study of 71 cases, have found $14 \%$ head injury and $40 \%$ chest injuries which included hemothorax (14\%), pneumothorax (6\%) and rib fractures 20\% (2). In our study group, 39 (25.32\%) chest injuries were present, most of them treated conservatively with intercostal tube drainage either for hemothorax or pneumothorax while 8 (20.15\%) required posterolateral thoracotomy for retained hemothorax.

Out of 81,26 (32.09\%) cases with abdominal injuries were missed during primary survey leading to delayed diagnosis and poor outcome. The reason being FAST negative at the time of presentation with masked clinical symptoms was related to abdominal injuries. This highlights the fact that cases with polytrauma need repeated examination at regular intervals by members of the trauma team, along with repeated radiological examination as and when required. CT scan remains the gold standard for the detection of solid organ injuries (29). In addition, a CT scan of the abdomen can reveal other associated injuries, notably vertebral and pelvic fractures and injuries in the thoracic cavity (30).

Our policy of initial management of all postoperative cases in the surgical ICU increased our survival rate as suggested by our low mortality rate of $11.6 \%$, whereas the reported mortality in other series was $6.1-26 \%$ (31). We observed acute renal failure in $12(7.7 \%)$ cases. Out of these 12 cases, 5 (41.6\%) presented with shock in the emergency department while the remaining 7 (58.3\%) developed renal failure in the postoperative period. Three (25\%) died despite undergoing hemodialysis in the postoperative period because of multiorgan dysfunction. We observed that it is necessary to have adequate infrastructure for hemodialysis, and a nephrologist should be a core member of trauma teams. Other complication includes bowel anastomotic leak, seen in $3(1.94 \%)$ cases, which were conservatively managed as controlled enterocutaneous fistula with total parental nutrition. Two cases of pancreatic fistula, developed on postoperative day 4 after distal spleenopancreatectomy, were given octreotide treatment during their stay in the hospital and both of them responded to the treatment. Nine (5.8\%) cases who developed septicemia were treated with broad-spectrum antibiotics in the surgical ICU. In our study, the initial nonoperative treatment rate was $58.44 \%$, with an approximate success rate of $90 \%$, a finding which is higher as compared with other reported series (32). We accept that the complication rate of $16.88 \%$ and the surgical intervention rate of $37 \%$ in our study was higher but comparable with the other reported studies where the reported rate was 10 to $27 \%(33,34)$. The learning curve of the treating trauma team as well as the supporting paramedical staff was one of the predominant contributory factors. Others were being lack of infrastructures such as non-availability of digital subtraction angiography (DSA) and lack of experience of the supporting staff (nurses) in trauma care. Efforts are going on to rectify these obstacles and we hope in the near future that we will be able to improve our services by leaps and bounds. Limitations of our study include retrospective design, small sample size because of the low influx of cases, and short follow-up period as these are the initial data from a newly created trauma centre.

\section{CONCLUSION}

The study revealed that among 154 cases of fatal blunt abdominal trauma, road traffic crash was the most common cause of blunt abdominal trauma, predominantly affecting males. The visceral and peritoneal injury frequently perceived was liver in 40 cases (25.9\%), spleen in 66 (43\%), intestine in 21(13.6\%) and kidney in 13 cases (9\%). Abdominal injury was associated with other injuries like head, chest and extremity injuries in 52.5\% cases. Duration of injury, presence of associated injury and preoperative ventilation requirement were independent predictors of mortality apart from contributary factors such as clinical presentation, organ involved and presence of complications.

Ethics Committee Approval: Ethics committee approval was granted for this study from the ethics committee of Sanjay Gandhi Institute of Medical Sciences (Ethics No. PGI/BE/437/2020). Subjects were enrolled in the study after obtaining voluntary informed consent according to the Declaration of Helsinki.

Peer-review: Externally peer-reviewed.

Author Contributions: Concept - A.S.; Design - A.S.; Supervision - G.P.; Data Collection and/or Processing - P.M.; Analysis and/or Interpratation P.M.; Literature Review - K.V., R.S.; Writing Manuscript - A.S.; Critical Reviews - R.S., G.P.

Conflict of Interest: The authors have no conflicts of interest to declare.

Financial Disclosure: The authors declared that this study has received no financial support.

\section{REFERENCES}

1. Aldemir M, Tacyildiz I, Girgin S. Predicting factors for mortality in the penetrating abdominal trauma. Acta Chir Belg 2004; 104(4): 429-34. CrossRef

2. Mehta N, Babu S, Venugopal K. An experience with blunt abdominal trauma: evaluation, management and outcome. Clin Pract 2014; 4(2): 599. CrossRef

3. Townsend CM Jr, Beauchamp RD, Evers BM, Mattox KL. Sabiston Text Book of Surgery. $18^{\text {th }} \mathrm{ed}$. The Biological Basis of Modern Surgical Practice Philadelphia: Elsevier-Saunders; 2008; 512. [CrossRef] 
4. Gad MA, Saber A, Farrag S, Shams ME, Ellabban GM. Incidence, patterns, and factors predicting mortality of abdominal injuries in trauma patients. N Am J Med Sci 2012; 4(3): 129-34. CCrossRef]

5. Jansen JO, Yule SR, Loudon MA. Investigation of blunt abdominal trauma. BMJ 2008; 336(7650): 938-42. [CrossRef]

6. Watts DD, Fakhry SM. Incidence of hollow viscus injury in blunt trauma: an analysis from 275,557 trauma admissions from the EAST multi-institutional trial. J Trauma 2003; 54(2): 289-94. [CrossRef]

7. Bloom Al, Rivkind A, Zamir G, Gross E, Kluger Y, Reissman P, et al. Blunt injury of the small intestine and mesentery -the trauma surgeon's Achilles heel? Eur J Emerg Med 1996; 3(2): 85-91. [CrossRef]

8. Nolan BW, Gabram SG, Schwartz RJ, Jacobs LM. Mesenteric injury from blunt abdominal trauma. Am Surg 1995; 61(6): 501-6. [CrossRef]

9. Howes N, Walker T, Allorto NL, Oosthuizen GV, Clarke DL. Laparotomy for blunt abdominal trauma in a civilian trauma service. S Afr J Surg 2012; 50(2): 30-2. [CrossRef]

10. Tan W, Chen C, Chiang H. The value and role of computed tomography in blunt injury of the abdomen. Zhonghua Yi Xue Za Zhi (Taipei) 1991; 48(2): 116-20. [CrossRef]

11. Fakhry SM, Brownstein M, Watts DD, Baker CC, Oller D. Relatively short diagnostic delays ( $<8$ hours) produce morbidity and mortality in blunt small bowel injury: an analysis of time to operative intervention in 198 patients from a multicenter experience. J Trauma 2000; 48(3): 408-14. CCrossRef

12. Nishijima DK, Simel DL, Wisner DH, Homles JF. Does this adult patient have a blunt intra-abdominal injury? JAMA 2012; 307(14): 1517-27. [CrossRef

13. Rizzo MJ, Federle MP, Griffiths BG. Bowel and mesenteric injury following blunt abdominal trauma: evaluation with CT. Radiology 1989; 173(1): 143-8. [CrossRef]

14. Salimi J, Ghodsi M, Zavvarh MN, Khaji A. Hospital management of abdominal trauma in Tehran, Iran: a review of 228 patients. Chin J Traumatol 2009; 12(5): 259-62. [CrossRef]

15. Fleming S, Bird R, Ratnasingham K, Sarker SJ, Walsh M, Patel B. ACcuracy of FAST scan in blunt abdominal trauma in a major London trauma centre. Int J Surg 2012; 10(9): 470-74. [CrossRef]

16. Farahmand N, Sirlin CB, Brown MA, Shragg GP, Fortlage D, Hoyt DB, et al. Hypotensive patients with blunt abdominal trauma: Performance of screening US. Radiology 2005; 235(2):436-43. [CrossRef]

17. Karamercan A, Yilmaz TU, Karmercan MA, Aytac B. Blunt abdominal trauma: Evaluation of diagnostic options and surgical outcomes. Ulus Travma Acil Cerrahi Derg 2008; 14(3): 205-10. [CrossRef]

18. Kornezos I, Chatziioannou A, Kokkonouzis I, Nebotakis P, Moschouris $H$, Yiarmenitis $S$, et al. Findings and limitations of focused ultrasound as a possible screening test in stable adult patients with blunt abdominal trauma: A Greek study. Eur Radiol 2010;20(1):234-8. [CrossRef]
19. Smith ZA, Wood D. Emergency focussed assessment with sonography in trauma (FAST) and haemodynamic stability. Emerg Med J 2014; 31(4): 273-7. [CrossRef]

20. Matthes G, Stengel D, Seifert J, Rademacher G, Mutze S, Ekkernkamp A. Blunt liver injuries in polytrauma: Results from a cohort study with the regular use of whole-body helical computed tomography. World J Surg 2003; 27(10): 1124-30. [CrossRef]

21. Clancy TV, Gary Maxwell J, Covington DL, Brinker CC, Blackman D. A statewide analysis of level I and II trauma centers for patients with major injuries. J Trauma 2001; 51(2): 346-51. [CrossRef]

22. Smith J, Caldwell E, DAmours S, Jalaludin B, Sugrue M. Abdominal trauma: a disease in evolution. ANZ J Surg 2005; 75(9): 790-4. CrossRef

23. Jagannatha R, Vishwanath D, Ananda K. Pattern of abdominal injuries in cases of road traffic accidents. Indian J Forensic Med \& Toxicol 2012; 6(1): 30-2. [CrossRef]

24. Khichi Z, Afridi HK, Mateen A, Kahriri GQ. Audit of thoraco-abdominal injuries in road traffic accidents in Larkana-autopsy study. Pak J Med \& Health Sci 2013; 7(4): 1109-12. [CrossRef]

25. Meng MV, Brandes SB, MCAninch JW. Renal trauma: indications and techniques for surgical exploration. World J Urol 1999; 17(2): 71-7. [CrossRef]

26. Sah D, Sinha SP. Pattern of abdominal injuries in a tertiary care centre in Western UP. AIMDR 2016; 2(6): 5-9. [CrossRef

27. Singh $M$, Kumar A, Verma AK, Kumar S, Singh AK. Abdominal organ involvement in blunt injuries. J Indian Acad forensic Med 2012; 34(1): 24-6. [CrossRef]

28. Umare GM, Sharekar N, Motewar A. Study of clinical profile and management of blunt abdominal trauma. IJCMR 2018; 5(1): 5-9. [CrossRef]

29. Wing VW, Federle MP, Morris JA, Jeffrey RB, Bluth R. The clinical impact of CT for blunt abdominal trauma. Am J Roentgenol 1985; 145(6): 1191-4. CrossRef

30. Hamidi MI, Aldaoud KM, Qtaish I. The role of computed tomography in blunt abdominal trauma. Sultan Qaboos Univ Med J 2007; 7(1): 416. [CrossRef]

31. Raza M, Abbas Y, Devi V, Prasad KV, Rizk KN, Nair PP. Non operative management of abdominal trauma - a 10 years review. World J Emerg Surg 2013; 8: 14. CrossRef.

32. Pande R, Saratzis RA, Beatty JW, Dooran CN, Kirby R, Harmston C. Contemporary characteristics of blunt abdominal trauma in a regional series from the UK. Ann R Coll Surg Engl 2017; 99(1): 82-7. [CrossRef]

33. Arumugam S, Al-Hassani A, El-Menyar A, Abdelrahman H, Parchani A, Peralta $R$, et al. Frequency, causes and pattern of abdominal trauma: A 4-year descriptive analysis. J Emerg Trauma Shock 2015; 8(4): 193-8. CrossRef

34. Goedecke M, Kühn F, Stratos I, Vasan R, Pertschy A, Klar E. No need for surgery? Patter and outcomes of blunt abdominal trauma. Innov Surg Sci 2018; 4(3): 100-7. [CrossRef] 


\title{
ORIJINAL ÇALIŞMA-ÖZET
}

Turk J Surg 2021; 37 (3): 277-285

\section{Künt batın travmasından alınan dersler: Birinci seviye travma merkezinin cerrahi deneyimi}

\author{
Amit Singh ${ }^{1}$, Ganpat Prasad ${ }^{2}$, Prabhakar Mishra ${ }^{3}$, Kuldeep Vishkarma ${ }^{4}$, Rafat Shamim² \\ 1 Şangay Gandhi Lisansüstü Tıp Bilimleri Enstitüsü, Travma Birimi, Lucknow, Hindistan \\ 2 Şangay Gandhi Lisansüstü Tıp Bilimleri Enstitüsü, Anestezi Birimi, Lucknow, Hindistan \\ ${ }^{3}$ Şangay Gandhi Lisansüstü Tıp Bilimleri Enstitüsü, Biyoistatistik Birimi, Lucknow, Hindistan
}

\section{ÖZET}

Giriş ve Amaç: Kaza sayısı gün geçtikçe artarken zorlukları da beraberinde getirmektedir. Hükümet, travma tedavisine vurgu yaparak, 2018 yılının Haziran ayında, Kuzey Hindistan'da 2,8 milyonluk bir nüfusa hizmet veren 120 yataklı 1. seviye bir travma merkezini hizmete geçirdi. Bu makale aracılığıyla, yeni bir seviye I travma merkezinden künt batın travması yönetimi deneyimlerimizi paylaşmayı hedefledik.

Gereç ve Yöntem: Bu geriye dönük gözlemsel çalışmada, Temmuz 2018'den Mart 2020'ye kadar mevcut tüm kayıtların tarihsel analizi yapıldı. Çalışmaya dahil edilme kriterleri, ilişkili yaralanmalarla birlikte veya yaralanmalar olmaksızın künt batın travmasıydı. Yaş, cinsiyet, yaralanma mekanizması, hastaneye ulaşma süresi, katı organlar ve içi boş organ yaralanmaları, ilişkili ekstra abdominal yaralanmalar, tedavi şekli, komplikasyonlar, YBÜ ve hastanede kalış süresi ve mortalite ile ilgili veriler gözden geçirildi.

Bulgular: Genel olarak, çalışma süresi boyunca 154 vaka batın yaralanmalarına maruz kaldı. Yüzde yetmiş beşi erkekti. Künt batın travmasının en yaygın nedeni karayolu trafik kazalarıydı. $57(\% 37,01)$ vakada cerrahi yönetim gerekli olurken, $97(\% 62,98)$ vakada nonoperatif (NOM) tedavi uygulandı. Ortalama YBÜ kalış süresi 05.73 gün, ortalama hastanede kalış süresi 12 gün (dağııım 10-60 gün) idi. Gerçekleştirilen prosedürler arasında splenektomi, karaciğer onarımı, bağırsak yaralanmasının birincil kapatılması ve stoma oluşumu yer alır. Vakaların \%16,88'inde komplikasyonlar meydana geldi ve genel ölüm oranı \%11,68 idi.

Sonuç: Çalışma, 154 ölümcül künt batın travması olgusu arasında, karayolu trafik kazasının, ağırlıklı olarak erkekleri etkileyen künt batın travmasının en yaygın nedeni olduğunu ortaya koydu. Sıklıkla algılanan viseral ve periton yaralanması 40 olguda $(\% 25,9)$ karaciğer, $66(\% 43)$ olguda dalak, $21(\% 13,6)$ olguda bağırsak ve 13 olguda (\%09) böbrek idi. Batın yaralanması \%52,5 olguda kafa, göğüs ve ekstremite yaralanmaları gibi diğer yaralanmalarla ilişkilendirildi. Yaralanma süresi, ilişkili yaralanmanın varlığı ve ameliyat öncesi vantilasyon gereksinimi, klinik görünüm, tutulan organ ve komplikasyonların varlığı gibi katkıda bulunan faktörlerin yanı sıra, mortalitenin bağımsız belirleyicileriydi.

Anahtar Kelimeler: Motorlu taşıt kazaları, travma, batın yaralanmaları, sonuç, hastane öncesi bakım

DOi: $10.47717 /$ turkjsurg.2021.4886 